\title{
Impact of Microfinance on Income and Employment of Women in Jigjiga, Ethiopia
}

Submitted 25/11/20, $1^{\text {st }}$ revision 18/12/20, $2^{\text {nd }}$ revision 09/02/21, accepted 20/03/21

\author{
Perways Alam ${ }^{1}$, Imran Azad ${ }^{2}$
}

\begin{abstract}
:
Purpose: This paper aims to analyze the impact of microfinance on the income and employment of women participants in Jigjig city.

Design/Methodology/Approach: A survey of 146 active clients of the Somali Microfinance and Ray Microfinance in Jigjiga, Somali Regional State (Ethiopia), has been undertaken for this purpose. Statistical and econometric techniques are used to explore the impact of microfinance.

Findings: It is found that microfinance credit positively affects income generation and employment level of women, and the impact on productive activities is higher, and it increases the income of women participants.

Practical Implications: It concluded from the study that to maximize the benefits of MFIs, MFIs should develop a different approaching mechanism to deliver their services and products at large for the poorest of the poor, like having an appropriate selection mechanism of the poor in the scheme that emphasize women, less educated and rural poor people and it is advisable to have innovative product and service together with the formulation of enabling regulation.

Originality/Value: To the best of the authors' knowledge, no other paper attempted to study the impact of microfinance on women participants' income and employment in Jigjig city. This study will provide an opportunity for the policymaker to focus more on microcredit to help women for their upliftment.
\end{abstract}

Keywords: MFIs, income, employment, micro-credit.

JEL codes: G20, G21, G28.

Paper Type: Research study.

\footnotetext{
${ }^{1}$ Associate Professor, Dept. of Accounting and Finance, Jigjiga University, Jjgjiga, Ethiopia,perwaysl@rediffmail.com

${ }^{2}$ Assistant Professor, Department of Business Administration, College of Applied Sciences, Salalah, University of Technology \& Applied Sciences, Sultanate of Oman, imran.sal@cas.edu.om
} 


\section{Introduction}

Along with other developing countries, Ethiopia has adopted microfinance in its strategy for increasing income and generates employment. Microfinance has been depicted as an efficient tool for increasing income and employment and empowering women, and fostering equality in society. However, poverty alleviation and development is not only about income enhancement or meeting peoples' basic needs, but it is also about offering caregivers and their children an opportunity for a better life. This study conducted in Jigjiga attempts to determine the impact of microfinance on women's income and employment in Jigjiga.

Two microfinance institutions are working in Jigjiga Somali Microfinance Institution Share Company (SMFISC) and Rays. SMFISC has 23 branches in the region, and Ray's microfinance institution has 4 branches in the region. Two branches, out of these 27 branches located in the Jigjig, have been considered for the study.

\subsection{Statement of Problem}

There are many studies related to microfinance and its impact on income and employment across the world. Whereas in Ethiopia, the introduction of MFIs is seen as the best strategy and source of financial services for low-income earners to raise their income and reduce their poverty level, knowledge about the achievement of the intended poverty alleviation objective by microfinance strategies remains scanty. There are limited studies conducted regarding the microfinance industry in Ethiopia, but they focused on sustainability and outreach of microfinance, challenges and prospects of the microfinance institution, microfinance institution's financial performance, and regulating microfinance institution in Ethiopia. Particularly the studies related to the impact of microfinance on income and employment are inconclusive, very narrow, and not overview the institution's effect by tying with other outcomes of the program and not free of methodological limitation.

Hence, having the above gaps, this study aimed to fill the knowledge gap and presumes tremendous importance for the area by integrating and examining essential issues related to MFIs and their contribution in women poverty reduction in Jigjiga, Ethiopia.

\subsection{Research Questions}

Through the course of this research it intends to provide answers to the following research questions:

1. What is the impact of microfinance on the income of women beneficiaries?

2. What is the impact of microfinance on the employment of women beneficiaries? 


\subsection{Objective of the Study}

The main research objectives of this research are:

1. To study the impact of microfinance on the income of women beneficiaries.

2. To study the impact of microfinance on the employment of the women beneficiaries.

\section{Literature Review}

\section{Empirical Studies Related to Microfinance and it's Impact on Income and} Employment:

Montgomery (2005) examined the impact of Khushhali Bank's lending program on common household welfare. The study was carried out in Pakistan by surveyed 1454 clients and 1427 non-clients respondents. The conclusion for the empirical analysis of the study revealed that the Khushhali bank microcredit program has a positive impact on both economic and social indicators of welfare and incomegenerating activities, especially for the lowest participant in the program.

Mosley (2010) aimed to assess microfinance impact on poverty in Bolivia and do this through small sample surveys on four microfinance institutions. The study found that all the institutions studied positively impact income and asset levels. Moreover, the study also found that the more successful low-income borrowers have voluntary savings deposits. The researcher finally suggested some actions to be promising by institutions for further poverty reduction. They need to have more vigorous efforts to mobilize rural savings for their study in Adamawa state, Nigeria (Nudamatiya, Giroh, and Shehu, 2010). The overall result of the study showed that microfinance has a positive impact on the income of beneficiaries. For more achievement of the microfinance institution's objectives, the policy should address issues of inadequate access and high-interest rates together with capacity building in the beneficiaries. It is also recommended that policy focus on growth and development issues, which are noted to be critical to the successful use of microfinance as a poverty reduction tool.

Prasad and Gyawali (2011) assessed the role of microfinance in micro-enterprises creation and employment generation, a case of Paschimanchal Grameen Bikash Bank (PGBB), Nepal. Data required to carry out this study were obtained from the primary source through field survey, direct interview, and observation, and secondary sources of information were also used for the study. The sample size for the study was 115 randomly selected members. The researchers found that the purpose of the loan took by the respondents was to start a small-scale business, so the microfinance program has a positive impact and vital role in enterprise creation and employment generation. It is found to be an instrument of starting microenterprises.

Mamun et al. (2011) studied the effect of microcredit on Employment in Peninsular Malaysia to examine how participation affects the employment rate using a cross- 
sectional study design. The study's finding shows that participation in microcredit programs increases employment-generating opportunities at household and community levels. Based on the findings, the researcher suggested increasing the employment rate positively, the policy should be reviewed to provide training and diversified and flexible loan offers.

Asghar et al. (2012) conducted a study to assess the impact of microfinance by the Punjab Rural Support Program (PRSP) on poverty alleviation in district Sialkot's rural areas, Pakistan. The study's findings revealed that loan participation positively impacts the beneficial income, most of the beneficiaries shifted upward from the low class to the lower middle class.

Anthony and Isaac (2012) tried to examine the impact of microfinance on poverty alleviation. Based on the result, they found that microcredit loans housing index and estimated income positively impacted beneficiaries' welfare. At the same time, family size tends to reduce it, and the researchers concluded that access to the credit allowed the beneficiaries to take advantage of economic opportunities by providing a fundamental basis for planning and expanding business activities.

A comprehensive literature on microfinance impacts by Arora and Singhal (2013) reflected that microfinancing is the program that provides a broad range of financial services such as credit, saving, money transfers, and insurance to poor and lowincome households. In the development paradigm, microfinance has evolved as a need-based policy and program to cater to the neglected groups of society, especially women, poor, rural, deprived, etc. The basic idea of micro-finance is that, if poor people are provided access to financial assistance, including credit, they may start or expand a micro-enterprise that will allow them to break out of poverty. Micro-finance has become one of the most effective interventions for the economic empowerment of the poor.

Bhuiya, Khanam, and Rahman (2016) examined the impacts of microfinance on income and household consumption in Bangladesh that ultimately lead to poverty reduction. Results suggest that the overall impact of microfinance operations on the microfinance participants' economic well-being is positive.

Abera and Asfaw (2019) try to determine the impact of microfinance on Ethiopia's rural household. They found that microfinance services create employment opportunities, increase income, enhance empowerment, and aggregate, improve the livelihood of the poor.

In a similar pattern of previous studies to examine the impact of microfinance on the participants' income and employment, this study tried to examine the impact of microfinance towards income and employment from the lives of the women by employing descriptive and inferential statistics. 


\section{Research Design and Methodology}

The study population covers the women residents who have been engaged in microfinance activities and live in Jigjiga, Somali regional state. This research is survey research. Structured questionnaires were used to collect data from the beneficiaries of microfinance. The data has been analyzed through the descriptive statistics method and paired t-test, and the Wilcoxon signed ranks test is used to analyze the data using the SPSS software package.

The total numbers of beneficiaries (women) are 4,566 from Somali Microfinance Share Company and Rays Microfinance Institutions. Women credit beneficiaries of these two institutions are the populations of the study.

\subsection{Sampling Technique}

The sampling techniques used for the selection of the sample for the study were non-probabilistic. Under these two branches of the two microfinance institutions have selected proportionately women credit beneficiaries of both the institutions by lottery method.

The study has selected 151 sample respondents out of a total population of 4,566 beneficiaries in the selected two microfinance institutions. The study's sample size was calculated using the formula recommended by Yemane (1969) as cited by (Israel 2003). Questionnaires were distributed to 151 respondents, but 146 respondents have returned the questionnaires.

Descriptive statistics such as frequencies and percentages methods were used. For inferential statistics, paired t-test has used to find out the significance of microfinance on women's income and employment.

\section{Results and Discussion}

\subsection{Impact of Microfinance on Income of Participants}

The study presented in Table 1 shows that the average income of households before getting credit from microfinance is 5576.35 ETB. The average income of households after getting credit from microfinance is 12317.81 ETB. It shows that the average income of households' level is increased by $120.89 \%$. It can be concluded that microfinance credit helps and play an essential role for the respondents to increase their income.

This result also supported by the results of paired t-tests and accordingly, there exists a statistically significant difference in many households in terms of monthly income after and before getting microfinance from the microfinance institutions. 
Average monthly income increase after getting microfinance $(M=12,317.35$, $\mathrm{SE}=1965.91)$ compare to before getting microfinance $(\mathrm{M}=5576.35, \mathrm{SE}=399.25) \mathrm{t}=\mathrm{-}$ $3.54, \mathrm{df}=145, \mathrm{p}<.05$ Sig. (2-tailed) .001 .

Table 1. Impact of Microfinance on Income of the Respondents

\begin{tabular}{|c|c|c|c|c|c|}
\hline \multicolumn{6}{|c|}{ Paired Samples Statistics } \\
\hline & & Mean & $\mathrm{N}$ & Std. Deviation & $\begin{array}{c}\text { Std. Error } \\
\text { Mean }\end{array}$ \\
\hline \multirow[t]{2}{*}{ Pair 1} & $\begin{array}{l}\text { INCOME BEFORE } \\
\text { GETTING CREDIT FROM } \\
\text { MICROFINANCE }\end{array}$ & 5576.3493 & 146 & 4824.15166 & 399.24963 \\
\hline & $\begin{array}{l}\text { INCOME AFTER } \\
\text { GETTING CREDIT FROM } \\
\text { MICROFINANCE }\end{array}$ & 12317.8082 & 146 & 23754.14210 & 1965.90679 \\
\hline
\end{tabular}

Paired Samples Correlations
\begin{tabular}{|ll|r|r|c|}
\hline & \multicolumn{1}{c|}{ N } & Correlation & \multicolumn{1}{c|}{ Sig. } \\
\hline Pair 1 & INCOME BEFORE & 146 & .247 & .003 \\
& GETTING CREDIT FROM & & & \\
& MICROFINANCE \& & & & \\
& INCOME AFTER & & & \\
GETTING CREDIT FROM & & & \\
MICROFINANCE & & & \\
\hline
\end{tabular}

\begin{tabular}{|c|c|c|c|c|c|c|c|c|c|}
\hline \multicolumn{10}{|c|}{ Paired Samples Test } \\
\hline & & \multicolumn{5}{|c|}{ Paired Differences } & \multirow[b]{3}{*}{ t } & \multirow[b]{3}{*}{ df } & \multirow[b]{3}{*}{ Sig. (2-tailed) } \\
\hline & & \multirow[b]{2}{*}{ Mean } & \multirow[b]{2}{*}{ Std. Deviation } & \multirow{2}{*}{$\begin{array}{l}\text { Std. Error } \\
\text { Mean }\end{array}$} & \multicolumn{2}{|c|}{$\begin{array}{l}\text { 95\% Confidence Interval of the } \\
\text { Difference }\end{array}$} & & & \\
\hline & & & & & Lower & Upper & & & \\
\hline Pair 1 & $\begin{array}{l}\text { INCOME BEFORE } \\
\text { GETTING CREDIT FROM } \\
\text { MICROFINANCE- } \\
\text { INCOME AFTER } \\
\text { GETTING CREDIT FROM } \\
\text { MICROFINANCE }\end{array}$ & -6741.45890 & 23040.76157 & 1906.86700 & -10510.30441 & -2972.61340 & -3.535 & 145 & .001 \\
\hline
\end{tabular}

Source: Survey Data and Authors' Computation.

\subsection{Impact of Microfinance on Employment}

For developing economies, increasing the employment rate is the crucial objective where unemployment and underemployment are the primary cause of poverty. Different government and non-government sectors aim to enhance the chance of employment for the unemployed sustainably by using different developmental programs. The financial sectors are the lifeblood for the development of the country's economy as a whole. Since they can raise finance by extensive mobilization of saving from the people with surplus and used as a channel to transfer to the people with a deficit of finance to generate income and curve the effect of poverty. MFIs enable the poor to use the opportunity of improving their life by delivering various financial services. As a result, MFIs have a notable contribution to creating and preserving a job for the unemployed part of productive poor women. Accordingly, this section of the study examined Microfinance 
institution's contribution to creating employment opportunities for women by delivering financial services and products in the Jigjig region.

Table 2. Employment Status of Respondents

\begin{tabular}{|c|c|c|c|c|c|}
\hline \multirow{3}{*}{$\begin{array}{l}\text { Owning } \\
\text { income } \\
\text { generating } \\
\text { activity }\end{array}$} & \multicolumn{4}{|c|}{ Respondents } & $\begin{array}{l}\text { Wilcoxon } \\
\text { signed }\end{array}$ \\
\hline & \multicolumn{2}{|c|}{ Before } & \multicolumn{2}{|c|}{ After } & $Z=-7.488$ \\
\hline & Count & Percent & Count & Percent & 2 -sided $)=$ \\
\hline Yes & 81 & 55.48 & 146 & 100 & 0.000 \\
\hline No & 65 & 44.52 & - & - & \\
\hline Total & 146 & 100 & 146 & 100 & \\
\hline
\end{tabular}

Source: Survey Data and Authors' Computation.

The respondents' employment status is presented in Table 2, and it shows that the employment status in terms of owning income-generating activities of the respondents before and after joining microfinance institutions. Thus, before joining the institution, $55.48 \%$ of the respondents were owned income-generating activities, and $44.52 \%$ of them were not had their income-generating activity means they were laborers because of several reasons like they were financially destitute. However, after joining microfinance institutions, the employment status is wholly changed, and $100 \%$ of the respondents are enjoying different income-generating activities owned by them. Hence, because of participation or joining microfinance institutions and accessing the institution's financial services, $44.52 \%$ of unemployed households in a before condition have employment now.

The statistical test result also supports a significant difference between before and after the situation in terms of employment status $(\mathrm{P}<.05) .(\mathrm{Z}=-7.488$ Asymp.sig(2sided $=0.000$ ). Microfinance institutions contributed a significant part for the households to create income-generating activities. The studies by Prasad and Gyawali (2011), Mamun et al. (2011), and Bisrat and Paul (2011) also show the similar result of positive microfinance impact on a households employment status of the program participants in the post and pre-participation and compared to that of the non-participant households.

\section{Conclusion}

The analysis showed an impact of microfinance on the income and employment of women. After getting microfinance, the income of women respondents has increased, and it also increased women's employment. This result reflects that the role of MFI in increasing income and employment is crucial, and MFIs help empower women and reduce poverty.

Therefore, it is recommended that the government at all levels endeavor to assist microfinance institutions in functioning effectively in their mode of operation, as 
microfinance institutions have been found relevant in increasing the income level and employment level of women in Jigjiga. The establishment and implementation of legal and supervisory frameworks for microfinance institutions in Ethiopia make the country pioneer and recognizable in its effort in sub-Saharan African countries to strengthen the industry. MFIs are not able to reach all the needy women entrepreneurs. Thus, MFIs should develop a different approaching mechanism to deliver their services and products at large for the poorest of the poor like having an appropriate selection mechanism of the poor in the scheme that emphasizes women, less educated, and rural poor people, and it is advisable to have innovative product and service together with the formulation of enabling regulation.

\section{References:}

Abera, N., Asfaw, M. 2019. Impact of Microfinance on Rural Household Poverty in Ethiopia. Journal of Ecology \& Natural Resources, 3(5).

Addae, A. 2014. Causes of Poverty in Africa: A Review of Literature. American International Journal of Social Science, 3(7).

Aemfi-ethiopia. Retrieved from: http://www.aemfi-ethiopia.org/.

Anthony, A., Isaac, O. 2012. Impact of Microfinance on Poverty Alleviation in Ondo State, Nigeria. Australian Journal of Business and Management Research, 2(99), 31-37. Retrieved from: http://ajbmr.com/articlepdf/aus-29- 12i9n2a4.pdf.

Arif, G.M., Farooq, S. 2011. Poverty, Inequality and Unemployment in Pakistan, background Paper for the IDB Group MCPS Document for Pakistan. Pakistan institute of development economics and Islamic development bank.

Arora, B., Singhal, A. 2013. A Comprehensive Literature on Impacts of Microfinance. International Interdisciplinary Research Journal, 3(5). Retrieved from: http://www.oiirj.org/oiirj/sept-oct2013/38.pdf.

Asghar, N., Waqas, M., Ahmad, B. 2012. Role of Microcredit for Poverty alleviation in Pakistan: A Case Study of Punjab Rural Support Program. The international journal of Research journal of economics and business studies, 1(12).

Bhuiya, M.M.M., Khanam, R., Rahman, M.M. 2016. Impact of microfinance on household income and consumption in Bangladesh: Empirical evidence from a quasiexperimental survey. The Journal of Developing Areas, 50(3).

Bird, K., Hattel, K., Sasaki, E., Attapich, L. 2011. Poverty, Income Inequality, and Microfinance in Thailand. Asian development bank. Retrieved from: www.adb.org/.../poverty-income-inequality-microfinancethailand.Pdf.

Cyprian, A., Japheth, T. 2012. Microcredit as a Strategy for Poverty Reduction in Makurdi Local Government. International Journal of Humanities and Social Science, 2(12). Retrieved from: http://www.ijhssnet.com/journals/ Special_Issue_June_2012/22.pdf.

Emana, B. 2009. Cooperatives: a path to economic and social empowerment in Ethiopia. Series on the status of cooperative development in Africa. Retrieved from: http://www.ilo.org/public/english/employment/ent/coop/africa/download/wpno9c oop erativesinethiopia.pdf.

Kashif, M., Usman, A., Imran, M., Ahmad, S. 2011. Role of Micro Finance in Reducing Poverty: A Look at Social and Economic Factors. International Journal of Business and Social Science, 2(21). 
Mamun, A., Abdul, S., Malarvizhi, C. 2011. Examining the Effect of Microcredit on Employment in Peninsular Malaysia. Journal of Sustainable Development, 4(2). doi:10.5539/jsd.v4n2p174.

Mixmarket. Retrieved from: http://www.mixmarket.org/.

Montgomery, H. 2005. Serving the Poorest of the Poor: The Poverty Impact of the Khushhali Bank's Microfinance Lending in Pakistan.

Mosley, P. 2010. Microfinance and Poverty in Bolivia. The Journal of Development Studies, 101-132.

Nudamatiya, A.B., Giroh, D.Y., Shehu, J.F. 2010. Analysis of Micro-finance Impact on Poverty Reduction in Adamawa state, Nigeria. Journal of Agriculture \& Social Sciences, 6(4).

Prasad, H., Gyawali, M. 2011. Role of Microfinance in Employment Generation: A Case Study of Microfinance Program of Paschimanchal Grameen Bikash Bank. The Journal of Nepalese Business Studies, 7(1). Retrieved from: http://www.nepjol.info/index.php/JNBS/article/download/6401/5208.

UNDP. Retrieved from: http://www.undp.org/.

Wolday, A. 2004. The Development Microfinance Industry in Ethiopia: Current Status and the Prospect for Growth. Association of Ethiopian Microfinance Institutions. Addis Ababa, Ethiopia.

Worldbank. World development indicators, Retrieved from: http://data.worldbank.org/datacatalog/world-development-indicators.

Zohir, S., Matin, I. 2004. Wider impacts of microfinance institutions: issues and concepts. Journal of International Development. DOI: 10.1002/jid.1080. 